\title{
PENGARUH IKLIM ORGANISASI DAN KEDEWASAAN TERHADAP KINERJA KARYAWAN PADA PT GRAHA TUNGKI ARSITEKTIKA JAKARTA
}

\section{Vivi dan Rorlen}

Email: vivitanada@hotmail.com

Email: rorlen79@yahoo.com

\section{Penulis}

Rorlen adalah staf pengajar tidak tetap di Fakultas Ekonomi, Universitas Tarumanagara, Jakarta dan menjadi koordinator dalam bidang manajemen keuangan. Bidang peminatan: rumpun manajemen keuangan, rumpun manajemen operasional, perilaku konsumen..

\section{Abstrak}

Kemajuan ilmu pengetahuan dan teknologi begitu pesat telah menjadi era informasi. Hal ini dapat dilihat dari derasnya arus informasi dari segala penjuru dunia yang dapat diakses oleh siapapun tanpa batas ruang dan waktu.

Keberhasilan pembangunan teknologi informasi telah mempengaruhi semua aspek kehidupan manusia: seperti aspek ekonomi, sosial, budaya dan sebagainya sehingga terjadilah arena kompetisi untuk memperebutkan semua kepentingan manusia. Bagi masyarakat negara maju, hal ini mempunyai keuntungan yang optimal, karena mereka memiliki sumber daya manusia (SDM) yang berkualitas tinggi mampu bersaing pada pasar global. Namun sebaliknya merupakan masalah bagi masyarakat di negara-negara yang memiliki sumber daya manusia (SDM) rendah. Bukan hanya masalah ekonomi yang semakin terpuruk, namun juga budaya dan aspek kehidupan lainnya.

\section{Kata Kunci}

Iklim Organisasi, Kedewasaan, Kinerja

\section{PENDAHULUAN}

Untuk menghasilkan sumber daya manusia (SDM) yang berkualitas diperlukan individu yang senantiasa berdedikasi tinggi, dan profesional, yang mampu memberikan sumbangan berarti bagi perusahaan. Di dalam melaksanakan tugas pokok, tanggungjawab, wewenang dalam bidang kegiatannya, SDM dari level atasan sampai pada para karyawan tingkat bawah, perlu faktor-faktor pendukung di 
antaranya iklim organisasi dan kedewasaan (kematangan) untuk meningkatkan kinerja.

Iklim organisasi terkait erat dengan proses menciptakan lingkungan kerja yang kondusif, sehingga dapat tercipta hubungan dan kerjasama yang harmonis di antara seluruh anggota organisasi. Upaya untuk menciptakan iklim organisasi yang kondusif, khususnya hubungan kerja antara karyawan yang satu dengan karyawan yang lain dalam hubungan karyawan dengan pimpinan, diarahkan terwujudnya kerjasama kerja yang serasi. Dengan demikian, iklim organisasi yang harmonis dapat mewujudkan kinerja yang semakin lebih baik pada diri karyawan. Sedangkan faktor kedewasaan adalah faktor internal individu karyawan yang mempengaruhi pola kerja seseorang dalam suatu organisasi.

Kedewasaan merupakan kematangan secara psikologis, yaitu adanya beberapa karakteristik psikis yang membedakan sikap seorang yang telah dewasa dengan yang belum, seperti adanya orientasi pada tugas bukan pada ego, dapat mengendalikan perasaan pribadi, mengutamakan objektivitas, menerima kritik dan saran, dan sebagainya. Peningkatan kinerja juga berarti kemampuan untuk mengembangkan diri, baik secara formal maupun nonformal.

\section{IKLIM ORGANISASI}

Pengertian Iklim organisasi dapat didekati dari dua pengertian yaitu organisasi dan iklim organisasi. Hal ini seperti diungkapkan oleh Boone dan Kurtz, dikutip Basu Swastha (2002: 130) yang memberikan definisi mengenai organisasi sebagai suatu proses tersusun yang orang-orangnya berinteraksi untuk mencapai tujuan. Sedangkan iklim organisasi merupakan kualitas dari proses tersebut dalam suatu organisasi untuk mencapai tujuan yang telah ditetapkan.

Tampaknya iklim organisasi memiliki sifat-sifat yang tumpang tindih dengan konsep Budaya. Hal ini senada dengan pendapat Poole yang dikutip Monks (2002: $120)$ yang menjelaskan secara keseluruhan, iklim organisasi lebih merupakan sifat budaya dari pada merupakan suatu pengganti budaya. Sebagai suatu sistem kepercayaan yang di generalisasikan, iklim organisasi berperan dalam keutuhan suatu budaya dan membimbing perkembangan budaya tersebut. Hal ini serupa pendapat Kopelman, Brief, dan Guzzo, (1999: 90) bahwa budaya organisasi menyediakan konteks tempat yang relatif tetap bagi iklim organisasi.

Jadi dari pendapat para ahli tersebut di atas dapat dinyatakan bahwa pemahaman iklim komunikasi organisasi dapat mengulas mengenai budaya
organisasi.

Greenberg, J. and R.A. Baron (1993: 113) yang menyebutkan beberapa dimensi iklim organisasi sebagai berikut:

1. Kepercayaan (dimana setiap karyawan harus berusaha keras dalam mengembangkan dan mempertahankan hubungan yang didalamnya terdapat keyakinan dan kredibilitas yang didukung oleh pernyataan dan tindakan).

2. Pembuatan keputusan bersama / Dukungan (para karyawan disemua tingkat dalam organisasi harus diajak komunikasi dan berkonsultasi mengenai semua masalah dalam semua kebijakan organisasi yang relevan dengan kedudukan mereka serta berperan serta dalam pembuatan keputusan dan penetapan tujuan). 
3. Kejujuran (suasana umum yang diliputi kejujuran dan keterusterangan harus mewarnai hubungan dalam organisasi, dan karyawan mampu mengatakan apa yang ada di pikiran mereka).

4. Komunikasi (karyawan organisasi relatif tahu akan informasi yang berhubungan dengan tugas mereka).

5. Fleksibelitas / Otonomi (karyawan di setiap tingkat dalam organisasi mempunyai kekuatan pada diri sendiri yang mana dapat menerima saran ataupun menolak dengan pikiran terbuka).

6. Resiko Pekerjaan (adanya komitmen dalam organisasi tentang pekerjaan resiko tinggi, kualitas tinggi dan produktivitas tinggi dengan menunjukkan perhatian besar pada anggota lainnya ).

\section{KEDEWASAAN}

Kedewasaan seseorang dalam bekerja dapat dilihat dari beberapa aspek yaitu: aspek biologis dan psikologis. Di lihat dari aspek biologis menurut pendapat E.B Hurlock (dalam Mappiere, 2001: 15), menyamakan istilah "kedewasaan" dengan istilah "kematangan" secara biologis, yaitu sejak mulainya masa pubertas (yaitu dari umur 17 tahun). Masa itu disebut sebagai "adult" (dewasa) atau "adulthood" (status dalam keadaan dewasa).

Sedangkan J.E. Anderson (dalam Mappiere, 2001: 16) lebih menekankan istilah "kedewasaan" dengan kematangan secara psikologis, yaitu adanya beberapa karakteristik psikis yang membedakan sikap seorang yang telah dewasa dengan yang belum, seperti adanya orientasi pada tugas bukan pada ego, dapat mengendalikan perasaan pribadi, mengutamakan objektivitas, menerima kritik dan saran, dan sebagainya. Seperti halnya Anderson, F.J. Monks dan Knoers (2002: 318-319) lebih mengartikan kedewasaan dari sudut pandang psikologis. Dalam pandangan Monks dan Knoers, seseorang itu telah dikatakan dewasa bilamana dia telah mampu untuk memikul tanggung jawab bagi dirinya sendiri dan orang-orang lain yang dipercayakan kepadanya.

\section{KINERJA}

Whitmore (2002: 104) menyebutkan bahwa "kinerja" memiliki asal kata "kerja" artinya aktivitas yang dilakukan oleh seseorang atau organisasi dalam menjalankan tugas yang menjadi perkerjaannya. Kinerja artinya suatu perbuatan, suatu prestasi atau penampilan umum dari keterampilan.

Mangkunegara (2000: 97) mengatakan, bahwa istilah kinerja berasal dari kata "job performance" atau "actual performance" yaitu unjuk kerja atau prestasi sesungguhnya yang dicapai oleh seseorang dalam melaksanakan tugas sesuai dengan tanggung jawab yang diberikan kepadanya.

Sedermayanti (2000: 144) mengemukakan bahwa kinerja individu itu adalah bagaimana seseorang melaksanakan pekerjaannya atau unjuk kerja. Dari pengertian ini terlihat kinerja merupakan perbuatan atau proses yang dapat dinilai oleh orang lain.

Sentono (1999: 150) menyebutkan mengenai dimensi kinerja. Menurutnya, kinerja meliputi hasil keterampilan, prestasi dan sikap dari manusia. Sikap seseorang 
dapat termasuk di dalamnya yaitu integritas, loyalitas, kepribadian, ketaatan. Dalam penelitian ini, maksud dari kinerja adalah mengacu ke pengertian perbuatan, prestasi, dan keterampilan yang ditunjukkan oleh seseorang dalam melakukan pekerjaan dalam suatu organisasi/perusahaan, sehingga dapat dinilai mengenai kualitasnya, apakah kinerjanya rendah, sedang ataukah tinggi.

\section{PENGARUH KEDEWASAAN TERHADAP KINERJA}

Seperti disebutkan oleh Andi Mappiare (2001: 17), untuk mendefinisikan istilah "kedewasaan" (maturity) sangatlah sukar. Hal itu disebabkan, persepsi masing-masing orang terhadap kedewasaan sangat beragam.

Para ahli psikologi pun, dalam mendefinisikan kedewasaan banyak ditemukan perbedaan. F.J. Monks dan Knoers (2002: 318) menyebutkan tiga faktor yang menyebabkan kesukaran penelitian mengenai kedewasaan sehingga menyebabkan munculnya perbedaan pengertian di kalangan para ahli psikologi:

1. Pengertian perkembangan. Perkembangan sampai sekarang masih dipandang sebagai pemekaran kemampuan. Menurut pengertian ini pemekaran tersebut berhenti pada kurang lebih usia 20 tahun. Pada usia itu, maka semua kemampuan yang ada pada seseorang sudah berkembang.

2. Alasan metodologis. Orang dewasa lebih sukar dicapai daripada anak atau orang lanjut usia. Orang dewasa biasanya bekerja mencari nafkah dan tidak mudah diteliti seperti anak-anak di sekolah. Di samping itu, pada waktu yang lampau maka kebanyakan tes dibuat untuk anak-anak dan remaja, jadi tidak dimaksudkan untuk orang dewasa.

3. Kesukaran-kesukaran teknis. Dengan menjadi tuanya seseorang makin timbul perbedaan dan keanehan-keanehan pada mereka. Makin sukar untuk dapat menemukan hukum-hukum perkembangan yang umum, hingga harus bertolak dari variansi-variansi individual. Psikologi perkembangan orang dewasa harus bekerja lebih differensial daripada misalnya psikologi anak. Telah diusahakan untuk mengerti tingkah laku orang dewasa dengan menganalisis motif tingkah laku dan tindakan-tindakannya.

Hogan membuat model berupa gambar yang menunjukkan pengaruh antara dimensi kedewasaan di atas terhadap salah satunya kinerja seseorang dalam bekerja (job performance) (Hogan, "A Socioanalytic Model of Maturity", Journal of Carreer Assesment, 2004: 1). 


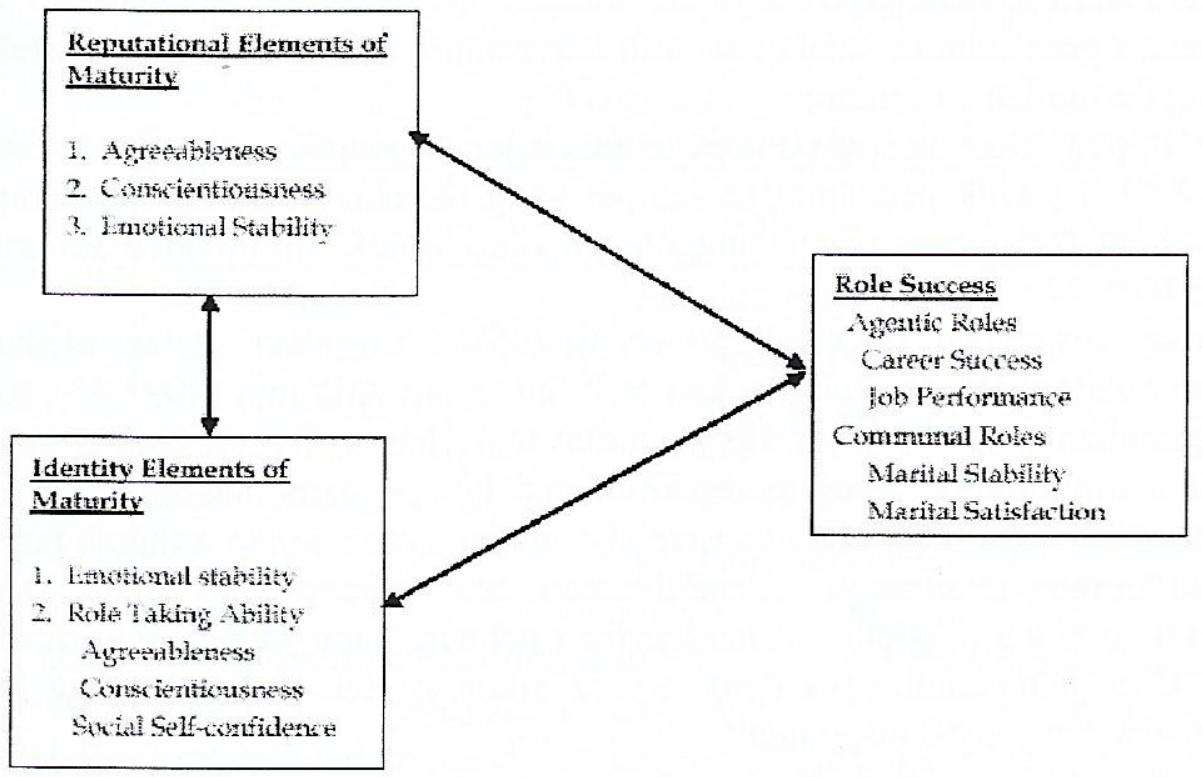

Sumber: Hogan, 2004: 1

Gambar 1.1

Pengaruh Kedewasaan terhadap Kinerja dalam Bekerja

Dari Gambar di atas dapat dilihat bahwa kedewasaan, yang di dalamnya mencakup dimensi kedewasaan yang di antaranya terdiri dari stabilitas emosi dan kemampuan mengendalikan diri berpengaruh terhadap kesuksesan di antaranya prestasi dalam bekerja (kinerja).

Secara lebih rinci, F.J. Monks dan Knoers (2002: 320) mengatakan, bahwa kedewasaan dapat ditinjau dari beberapa segi, yaitu: (a) sebagai suatu fase hidup, (b) sebagai suatu tingkat perkembangan biologis-somatis, (c) suatu tingkat perkembangan psikologis secara kemasyarakatan, dan (d) suatu tingkat perkembangan moral yang otonom yang menyebabkan individu mengadakan integerasi dalam orientasi nilai dan norma yang dipilihnya sendiri.

Allport (dalam Monk dan Knoers, 2002: 319) mengajukan 6 ciri orang yang memiliki psikologis dewasa. Ciri-ciri tersebut adalah:

1. Adanya usaha pribadi pada salah satu lapangan yang penting dalam kebudayaan, yaitu pekerjaan, politik, agama, kesenian dan ilmu pengetahuan.

2. Kemampuan untuk mengadakan kontak yang hangat dalam hubungan yang fungsional maupun yang tidak fungsional.

3. Adanya stabilitas batin yang fundamental dalam dunia perasaan dan dalam hubungan dengan penerimaan diri sendiri.

4. Pengamatan, pikiran dan tingkah laku menunjukkan sifat realitas yang jelas, namun masih ada relativismenya juga.

5. Dapat dilihat diri sendiri seperti adanya dan juga dapat melihat segi-segi kehidupan yang menyenangkan.

6. Menemukan suatu bentuk kehidupan yang sesuai dengan gambaran dunia, atau filsafat hidup yang merangkum kehidupan menjadi suatu kesatuan. 


\section{METODOLOGI PENELITIAN}

Populasi dalam penelitian ini adalah seluruh karyawan PT Graha Tungki Arsitektika, Jakarta yang berjumlah 110 orang.

Dalam pemilihan sampel pada penelitian ini menggunakan metode Probability Sampling, adalah teknik pengambilan sampel yang memberi peluang / kesempatan yang sama bagi setiap unsur atau anggota populasi untuk dipilih menjadi sampel (Sugiyono, 2006:77).

Jumlah responden sebanyak 50 orang (45\%) dirasakan telah memenuhi prinsip keterwakilan, seperti diungkapkan oleh Suharsimi Arikunto (1992:45), bahwa untuk pengambilan sampel dari jumlah yang luas maka harus diambil sampel minimal $10 \%$ dan juga dimaksudkan untuk mempermudah dalam pengambilan data.

Penentuan responden dilakukan melalui undian, yaitu setiap anggota populasi sebanyak 110 orang selanjutnya diambil secara acak sebanyak 50 orang. Dengan demikian, setiap anggota populasi mendapatkan peluang yang sama untuk dijadikan responden. Cara pengambilannya dengan cara dikocok. Setiap nomor yang keluar dicatat sampai sebanyak 50 responden.

Khusus untuk variabel Y (Kinerja pegawai), pertanyaan ditujukan bukan kepada pegawai tetapi pada 1 orang manajer HRD yang berwenang menilai kinerja 50 orang pegawai yang menjadi sampel. bawah ini:

Indikator iklim organisasi, kedewasaan, dan kinerja dapat dilihat dari tabel di

Tabel 1.1 : Operasionalisasi Variabel

\begin{tabular}{|l|l|c|}
\hline \multicolumn{1}{|c|}{ Variabel } & \multicolumn{1}{|c|}{ Indikator-Indikator } & Nomor Butir Kuesioner \\
\hline \multirow{5}{*}{ Iklim } & 1. Kepercayaan terhadap karyawan & 1,2 \\
Organisasi & 2. Kejujuran karyawan & 3,4 \\
& 3. Interaksi yang baik & 5 \\
& 4. Komunikasi & 6,7 \\
& 5. Kemandirian & 8 \\
& 6. Komitmen bersama dalam & 9,10 \\
& \multicolumn{1}{|c|}{ pencapaian tujuan } & \\
& & 11,12 \\
& 1. Berorientasi pada tugas & 13 \\
Kedewasaan & 2. Kebiasaan kerja yang efisien & 14 \\
& 3. Rasional (tidak emosional) & 15 \\
& 4. Obyektif & 16,17 \\
& 5. Menerima Kritik dan saran & 18,19 \\
& 6. Bertanggung jawab & 20 \\
\hline \multirow{5}{*}{ Kinerja } & 7. Penyesuaian terhadap situasi baru & $1,2,3$ \\
Karyawan & 1. Integritas & 5 \\
& 2. Loyalitas & 6,7 \\
& 3. Kepribadian & 10,8 \\
& 4. Prestasi Kerja & 4 \\
& 5. Ketaatan & 9 \\
\hline
\end{tabular}


Setiap pertanyaan kuesioner diberikan bobot dengan menggunakan skala likert.

Tabel 1.2

Tabel Pilihan dan Nilai Jawaban untuk Tiap Item Pertanyaan

\begin{tabular}{|c|c|}
\hline Nilai & Kategori \\
\hline 5 & Sangat Setuju (SS) \\
4 & Setuju (S) \\
3 & Netral (N) \\
2 & Tidak Setuju (TS) \\
1 & Sangat Tidak Setuju (STS) \\
\hline
\end{tabular}

Data yang diperoleh dikumpulkan melalui penyebaran kuesioner. Penulis mempersiapkan daftar pernyataan-pernyataan yang berhubungan dengan permasalahan yang ada dalam penelitian. Kuesioner yang diberikan berisi pernyataanpernyataan tertulis berbentuk pernyataan tertutup.

Perhitungan Validitas dilakukan dengan menggunakan bantuan software SPSS versi 13.0 dan dibandingkan dengan nilai $\mathrm{r}$ kritis ( $\mathrm{r}$ tabel).

Kriteria pengujian validitas:

$\mathrm{r}$ hitung $>\mathrm{r}$ tabel $=$ Valid

$\mathrm{r}$ hitung $<\mathrm{r}$ tabel $=$ Tidak valid

Atau dalam SPSS:

Sig $<0.05=$ Valid

Sig $>0.05=$ Tidak Valid

Reliabilitas pertanyaan dikatakan baik jika memiliki nilai Cronbach's Alpha > dari 0.60 (Ghozali, 2001:134).

Data yang berhasil dikumpulkan, kemudian akan diolah dengan uji regresi, uji $t$ dan uji $F$ untuk menguji pengaruh variabel independen/bebas yaitu iklim organisasi dan kedewasaan dengan variabel dependen/terikat yaitu kinerja karyawan.

Dalam penelitian ini statistik deskriptif berdasarkan karakteristik responden, meliputi: jenis kelamin, umur, pendidikan terakhir, dan jabatan.

Analisa regresi berganda digunakan untuk menguji pengaruh dua atau lebih variabel independen terhadap variabel dependen (Sugiyono, 2006:211)

Formulasi persamaan regresi adalah:

$\mathrm{Y}=\mathrm{a}+\mathrm{b}_{1} \mathrm{X}_{1}+\mathrm{b}_{2} \mathrm{X}_{2}$ berikut:

Hipotesis penelitian yang akan digunakan dalam penelitian ini, sebagai

$\mathrm{H}_{0} 1$ : Tidak terdapat pengaruh iklim organisasi terhadap kinerja karyawan.

$\mathrm{H}_{\mathrm{a}} \mathrm{I}$ : Terdapat pengaruh iklim organisasi terhadap kinerja karyawan.

$\mathrm{H}_{0} 2$ : Tidak terdapat pengaruh kedewasaan terhadap kinerja karyawan.

$\mathrm{H}_{\mathrm{a}} 2$ : Terdapat pengaruh kedewasaan terhadap kinerja karyawan.

$\mathrm{H}_{0} 3$ : Tidak terdapat pengaruh iklim organisasi dan kedewasaan terhadap kinerja karyawan.

$\mathrm{H}_{\mathrm{a}} 3$ : Terdapat pengaruh iklim organisasi dan kedewasaan terhadap kinerja karyawan. 
Untuk menguji persentase kontribusi variabel-variabel bebas terhadap variabel terikat dilakukan Uji Koefesien Penentu (KP) dengan menggunakan rumus :

$$
\mathrm{KP}=\mathrm{r}^{2} \times 100 \%
$$

\section{KESIMPULAN}

Berdasarkan hasil penelitian dan pembahasan yang telah dikemukakan sebelumnya mengenai pengaruh iklim organisasi dan kedewasaan terhadap kinerja karyawan pada PT Graha Tungki Arsitektika, Jakarta, maka diperoleh kesimpulan sebagai berikut

1. Pengaruh Iklim Organisasi dengan Kinerja Karyawan

Secara keseluruhan Iklim Organisasi pada PT Graha Tungki Arsitektika mempengaruhi secara signifikan terhadap Kinerja Karyawan. Hal ini ditunjukkan oleh perolehan nilai koefesien regresi yang menunjukkan pola pengaruh positif antara Iklim Organisasi dan Kinerja Karyawan, dan dari nilai uji t yang menunjukkan ditolaknya Ho.

2. Pengaruh Kedewasaan dengan Kinerja Karyawan

Secara keseluruhan Kedewasaan Karyawan PT Graha Tungki Arsitektika, mempengaruhi secara signifikan terhadap Kinerja Karyawan. Hal ini ditunjukkan oleh perolehan koefesien regresi yang menunjukkan pola pengaruh positif antara Iklim Organisasi dan Kinerja Karyawan, dan dari nilai uji t yang menunjukkan ditolaknya Ho.

3. Pengaruh Iklim Organisasi dan Kedewasaan dengan Kinerja Karyawan

Dari perhitungan regresi berganda, terbukti bahwa terdapat pengaruh yang positif dan signifikan antara Iklim Organisasi dan Kedewasaan dengan Kinerja Karyawan. Hal ini ditunjukkan oleh perolehan nilai koefesien regresi dan dari nilai uji F yang menunjukkan ditolaknya $\mathrm{Ho}$.

\section{DAFTAR PUSTAKA}

Achmad S. Ruky, (2001). Sistem Manajemen Peningkatan Mutu Sumber Daya Manusia. Jakarta: PT Gramedia.

Andi Mappiare,. (2001). Psikologi Orang Dewasa: Bagi Penyesuaian dan Pendidikan, Surabaya: Usaha Nasional.

Anwar Prabu Mangkunegara, (2000). Manajemen Sumber Daya Manusia

Perusahaan. Bandung: PT . Remaja Rosda Karya

Basu Swastha, (2002). Manajemen Pemasaran Modern, Yogyakarta: Liberty.

Gibson, James, L.John M, et.al. (1996). Organisasi: Perilaku, Struktur, Proses, Jilid I, Diterjemahkan oleh Nunuk Adiarni, Edisi Kedelapan. Jakarta: Binarupa Aksara.

Greenberg, J. and R.A. Baron. (1993). Behavior in Organizations 4th. ed. Allyn and Bacon, Boston.

Hogan, "A Socioanalytic Model of Maturity", Journal of Carreer Assesment, 2004: 1. 
Horrocks, John E. (1976) The Psychology of Adolescence, Boston: Houghton Mifflin, $4^{\text {th }}$ Edition.

Imam Ghozali, (2001). Aplikasi Analisis Multivariate dengan Program SPSS. Semarang: Badan Penerbit Univ Diponegoro.

Kopelman, Brief dan Guzo (1999). Organizational Climate and Culture, San Francisco: Jossey-Bass.

Kreitner dan Kinicki (1999). Organizational Learning: A Theory of Action Perspective Reading, Boston:Allyn and Bacon.

Monks, F.J. dan Knoers, A.M.P (2002). Psikologi Perkembangan: Pengantar dalam Berbagai Bagiannya, Yogyakarta: Gadjah Mada University Press, Cet. VIII.

Prawiro Sentono, (1999). Manajemen Sumberdaya Manusia: Kebijakan Kinerja Tenaga Kerja. Yogyakarta: BPPE.

Robbins, Stephen P. (2001). Organizational behavior : consepts, Controversies and Aplications. $3^{\text {rd }}$ edition, New Jersey: Prentice Hall.

Sedermayanti (2000). Tata kerja dan produktifitas kerja, Bandung: Mandor Jaya.

Sugiyono, (2006). Statistika untuk Penelitian, Bandung: Alfabeta

Suharsimi Arikunto, (1992). Prosedur penelitian: suatu pendekatan praktik, Jakarta: Rineka Cipta.

Whitmore, John. (2002). Coaching for Performance, Seni Mengarahkan untuk mendongkrak kinerja. Terjemahan Y.D Helly Purnomo. Jakarta: Gramedia. 